\title{
АДАПТАЦІЯ ВІТЧИЗНЯНОГО ЗАКОНОДАВСТВА ДО ЗАКОНОДАВСТВА ЄС ЯК СКЛАДОВА СВРОІНТЕГРАЦИЙНОГО КУРСУ УКРАЇНИ
}

\author{
О. С. Проневич
}

\begin{abstract}
Проневич О. С. Адаптація вітчизняного законодавства до законодавства ЄС як складова євроінтеграційного курсу України. Стаття присвячена осмисленню теоретико-доктринальних засад адаптації вітчизняного законодавства до законодавства Свропейського Союзу як одного 3 основоположних компонентів євроінтеграційного курсу України, з’ясування стану нормативноправового забезпечення євроадаптаційної діяльності, а також специфіки побудови і функціонування чинного національного євроадаптаційного інституційного механізму. Автором здійснено спробу узагальненого дефініціювання правової категорії «адаптація законодавства», виокремлено характерні ознаки процесу адаптації національного законодавства до законодавства Свропейського Союзу та артикуляції пропозицій щодо шляхів удосконалення національного механізму адаптації законодавства.
\end{abstract}

Ключові слова: адаптація законодавства; acquis communautaire; приблизна адекватність законів; пріоритетні сфери адаптації законодавства; інституційний механізм адаптації законодавства.

Проневич A. С. Адаптация отечественного законодательства к законодательству ЕС как составляющая евроинтеграционного курса Украины. Статья посвящена осмыслению теоретико-доктринальных основ адаптации отечественного законодательства к законодательству Европейского Союза как одного из основополагающих компонентов евроинтеграционного курса Украины, выяснению состояния нормативно-правового обеспечения евроадаптационной деятельности, а также специфики построения и функционирования действующего национального механизма адаптации законодательства. Автором осуществлена попытка обобщенного дефинициирования правовой категории «адаптация законодательства», выделены характерные признаки процесса адаптации национального законодательства к законодательству Европейского Союза и артикулированы предложения о возможных путях усовершенствования национального механизма адаптации законодательства.

Ключевые слова: адаптация законодательства; acquis communautaire; приблизительная адекватность законов; приоритетные сферы адаптации законодательства; институциональный механизм адаптации законодательства.

Pronevych $O$. S. Adaptation of national legislation to The European Union as part of The European integration course of Ukraine. This article is devoted to understanding the theoretical and doctrinal bases of adaptation of national legislation to The European Union as one of the fundamental components of The European integration course of Ukraine, to ascertain the state of the legal provision yevroadaptatsiynoyi activities as well as the specific construction and operation of the current national yevroadaptatsiynoho institutional mechanism. The author attempted generalized definitsiyuvannya legal category of "adaptation of" singled out the characteristic features of the process of adaptation of national legislation to EU legislation and the articulation of proposals on ways to improve the national mechanism approximation.

Keywords: adaptation of legislation; acquis communautaire; approximation of laws; priority areas of approximation of legislation; institutional mechanism for adaptation of legislation.

Європейська інтеграція є політико-правовим феноменом, зумовленим багатовіковим прагненням європейських народів консолідувати зусилля у розбудові спільного простору миру та взаєморозуміння, верховенства права, добробуту, соціальної справедливості, вільної торгівлі, безперешкодного пересування і комунікації, безпеки та правосуддя. Об'єктивним наслідком інтеграційних процесів стало конституювання Свропейського Союзу як унікального наднаціонального міждержавного об'єднання.

Євроінтеграція є цивілізаційним вибором українського народу, що грунтується на усвідомленні європейської ідентичності, належності до європейської цивілізації та спільності історичної долі з європейськими народами. Визначення євроінтеграції як стратегіч- 
ного орієнтиру, зовнішньополітичного пріоритету та ключової мети Української держави зумовлює необхідність імплементації європейських стандартів забезпечення прав і свобод людини, модернізації інститутів публічної влади на людиноцентристських засадах, подолання технологічної відсталості, покращання інвестиційного клімату, створення нових робочих місць, підвищення конкурентоспроможності вітчизняного виробника на європейському ринку, приєднання до структур спільної безпеки тощо. Вирішення цих стратегічних завдань неможливо без адаптації вітчизняного законодавства до законодавства Європейського Союзу.

Впродовж останнього часу в юридичній науці позначилася традиція дослідження окремих аспектів адаптації законодавства України до законодавства ЄС. Зазначену проблему розглядали переважно правники та фахівці у галузі державного управління (О. В. Баклан, С. В. Грищак, О. Л. Євглевська, Н. М. Пархоменко, О. В. Прилипчук, М. В. Трубіна, I. В. Яковюк та ін.). Водночас аналіз їх наукового доробку свідчить про певну архаїчність використовуваних парадигм, фактичну відсутність відповідних комплексних праць фундаментального характеру та необхідність розгляду адаптації законодавства на тлі динамічних євроінтеграційних процесів і викликів.

Метою статті є осмислення теоретико-доктринальних засад адаптації вітчизняного законодавства до законодавства Свропейського Союзу як одного з основоположних компонентів євроінтеграційного курсу України, з'ясування стану нормативно-правового забезпечення євроадаптаційної діяльності, а також специфіки побудови і функціонування чинного національного євроадаптаційного інституційного механізму.

Євроінтеграційна перспектива України в основному була окреслена Угодою про партнерство та співробітництво між Україною і Свропейськими Співтовариствами та їх державами-членами (УПС) від 14 червня 1994 року (набула чинності 1 березня 1998 року). Згідно з частиною 1 статті 51 УПС вперше актуалізовано проблему добровільного, часткового та поступового «зближення існуючого і майбутнього законодавства України з законодавством Співтовариства» («приведення законодавства України у відповідність до законодавства Співтовариства») шляхом встановлення «приблизної адекватності законів» (щоправда, без визначення прогнозованого ступеня сумісності законодавства, термінів ії досягнення, критеріїв оцінювання та санкцій за невиконання взятих зобов'язань) у 16 пріоритетних для зміцнення економічних зв'язків сферах (митне право, законодавство про компанії, банківське право, бухгалтерський облік компаній, податки, включаючи непрямі, інтелектуальна власність, охорона праці, фінансові послуги, правила конкуренції, державні закупівлі, охорона здоров'я та життя людей, тварин і рослин, навколишнє середовище, захист прав споживачів, технічні правила і стандарти, енергетика, транспорт) $)^{1}$. У Національній індикативній програмі на 2007-2010 роки було виокремлено обмежену кількість пріоритетних сфер (підтримку демократичного розвитку та якісного управління, підтримку регуляторної реформи і розширення адміністративних можливостей, підтримку розвитку інфраструктури) зближення із законодавством, процедурами, стандартами і практикою Європейського Союзу на основі цілей, визначених Угодою про партнерство і співробітництво та Планом дій Україна - СС. Цим документом фактично визначалися додаткові напрями (підпріоритети) адаптації законодавства України до acquis communautaire, а саме: покращання управління державними фінансами; вдосконалення систем інтегрованого управління державним кордоном; покращання управління міграційними потоками; інтеграція до європейського освітньо-дослідницького простору, налагодження міжлюдських контактів/обмінів. Водночас увага приділялася реалізації ліберального публічно-правового імперативу (зміцненню демократії та верховенства права, визнанню примату прав і свобод людини, забезпеченню належного врядування тощо) ${ }^{2}$. Національна індикативна програма на 2011-2013 роки створювала підгрунтя для інтенсифікації адаптаційно-правової діяльності у контексті забезпечення виконання завдань щодо сприяння набранню чинності Угоди про асоціацію між СС та Україною (включаючи створення поглибленої та всеохоплюючої зони вільної торгівлі) і забезпечення сталого розвитку . Натомість у додатку XVII «Нормативно-правове наближення» Угоди про асоціацію між Україною, з однієї сторони, та Європейським Союзом, Європейським співтовариством з атомної енергії і їхніми дер- 
жавами-членами, з іншої сторони*, закріплено перелік актів Свропейського Союзу, котрі підлягають «горизонтальній адаптації» у секторах, що потребують нормативно-правового наближення (фінансові послуги, телекомунікаційні послуги, поштові та кур'єрські послуги, послуги з міжнародних морських перевезень $)^{4}$.

Юридико-лінгвістичний аналіз україномовного тексту Угоди про партнерство та співробітництво між Україною і Свропейськими Співтовариствами та їх державами-членами свідчить про відсутність уніфікованого категоріально-термінологічного позначення процесу зближення законодавства України із законодавством СС. Зокрема, сторони Угоди одночасно оперують спорідненими категоріями «зближення» (ст. 51, 76), «приблизна адекватність законів» (ст. 51), «адаптація» (ст. 63, 77), «наближення» (ст. 60), «встановлення еквівалентних норм» (ст. 68). У науковому середовищі також відсутня єдина думка, що призвело до одночасного синонімічного використання термінів «адаптація законодавства», «гармонізація законодавства», «наближення законодавства» тощо.

Зазначена вище термінологічна еклектичність у вітчизняному законодавстві подолана шляхом легітимізації дефініції «адаптація законодавства». Так, у Стратегії інтеграції України до Європейського Союзу, затвердженій указом Президента України від 11.06.1998 № 615/98, адаптація законодавства трактується як зближення із сучасною європейською системою права, що забезпечить розвиток політичної, підприємницької, соціальної, культурної активності громадян України, економічний розвиток держави у рамках ЄС і сприятиме поступовому зростанню добробуту громадян, приведенню його до рівня, що склався у державах-членах $\mathrm{CC}^{5}$. У Концепції адаптації законодавства України до законодавства Європейського Союзу, схваленій постановою Кабінету Міністрів України від 16.08.1999 № 1496, адаптація законодавства тлумачиться як процес «зближення та поступового приведення законодавства України у відповідність із законодавством ЄС» ${ }^{6}$. Натомість відповідно до розділу II Загальнодержавної програми адаптації законодавства України до законодавства Європейського Союзу, затвердженої Законом України від 18.03.2004 № 1624-IV, адаптація законодавства визначена як планомірний процес приведення законів України та інших нормативно-правових актів у відповідність 3 acquis communautaire - у перекладі французькою мовою «надбання (доробок, здобуток) Співтовариства», тобто правової системи Європейського Союзу, що охоплює акти законодавства ЄС (але не обмежується ними), прийняті в рамках Європейського співтовариства, Спільної зовнішньої політики і політики безпеки і Співпраці у сфері юстиції та внутрішніх справ ${ }^{7}$.

Наголосимо, що в доктринально-правовому вимірі феномен acquis communautaire ширший, аніж правовий концепт «законодавство ЄС». Використання юридично коректної категорії acquis communautaire об'єктивно зумовлено відсутністю законодавства Європейського Союзу у класичному формально-юридичному сенсі як сукупності нормативно-правових актів, ухвалених уповноваженими органами публічної влади 3 дотриманням відповідної процедури їх прийняття і застосування. Натомість поняття «законодавство Європейського Союзу» дещо звужує сфери адаптації законодавства України, оскільки ним не охоплюються установчі договори $\mathcal{C}$, загальні принципи права $\mathcal{C}$, прецедентні рішення Суду $\mathrm{CC}$, «м'яке право» (акти, що не мають юридично обов'язкової сили). Джерелами acquis communautaire $€$ первинне (установчі договори, угоди про приєднання нових держав-членів, міжнародні договори між державами-членами з питань, віднесених

* Вчинена 21 березня та 27 червня 2014 року в м. Брюсселі; ратифікована Законом України № 1678-VII від 16 вересня 2014 року із заявою; з 1 січня 2016 року відповідно до статті 486 Угоди про асоціацію між Україною та ЄС тимчасово застосовуються такі положення цієї Угоди: розділ IV, за винятком статті 158 у тій мірі, в якій вона стосується забезпечення дотримання прав інтелектуальної власності під час кримінальних провадження, а також за винятком статей 285 і 286 у тій мірі, в якій ці статті застосовуються до адміністративних проваджень та перегляду й оскаржень на рівні держав-членів; розділ VII, за винятком статті 479(1) у тій мірі, в якій положення цього розділу обмежуються метою забезпечення тимчасового застосування Угоди; додатки I-XXV, а також Протоколи I та II. Див.: Щодо тимчасового застосування міжнародного договору: лист Міністерства закордонних справ України від 20 листопада 2015 року № 72/14-612/1-2980. - URL: http://zakon3.rada. gov.ua/rada/show/v2980321-15/paran2\#n2 (дата звернення: 23.08.2016). 
до компетенції СС) і вторинне (акти, прийняті інституціями СС для забезпечення реалізації установчих договорів) законодавство Європейського Союзу, а також сукупність актів незобов'язального характеру, доктринальних положень, рішень Суду СС, укладених європейськими співтовариствами рекомендацій і домовленостей, що беззастережно сприймаються державами-членами та державами-аплікантами на вступ до Європейського Союзу. Система acquis communautaire охоплює нормативний (правові доктрини, юридичні норми і принципи) та організаційний (сукупність правових інституцій) компоненти. Адаптація законодавства України до законодавства ЄС визнана «пріоритетною складовою процесу інтеграції України до Європейського Союзу», що у свою чергу є пріоритетним напрямом української зовнішньої політики. Натомість державна політика України щодо адаптації законодавства як складова частина правової реформи полягає у забезпеченні єдиних підходів до нормопроектування, підготовки кваліфікованих спеціалістів, а також «створення належних умов для інституціонального, науково-освітнього, нормопроектного, технічного, фінансового забезпечення процесу адаптації законодавства України» ${ }^{8}$

У вітчизняній юридичній науці упродовж останнього часу здійснюються спроби артикуляції догматико-теоретичних основ адаптації законодавства України до законодавства ЄС. Поняття «адаптація» у широкому сенсі тлумачиться як еволюційний процес, спрямований на коригування поведінки суб'єктів або вдосконалення структури системи з метою нейтралізації потенційного або реального негативного зовнішнього впливу, підвищення рівня життєздатності та ефективності функціонування. Натомість дефініція «адаптація національного законодавства до законодавства ЄС» осмислюється у контексті ії співставлення 3 вищеназваними спорідненими категоріями. Дослідники демонструють широкий спектр думок щодо визначення сутності адаптації національного законодавства до законодавства ЄС. Зокрема, наголошується на допустимості ії інтерпретації як правотворчого процесу використання міжнародного досвіду в національному законодавстві, одностороннього руху національної правової системи (включаючи законодавство, правотворчість, юридичну техніку, правозастосування) назустріч (або вслід) європейській правовій системі, пристосування чинних норм національного законодавства до норм законодавства ЄС відповідно до взятих державою міжнародних зобов'язань, комплексу односторонніх заходів з метою приведення національної законодавчої системи у відповідність до обов'язкового мінімуму законодавства Європейського Союзу (директив, рішень, регламентів, рекомендацій, резолюцій), зближення із сучасною європейською правовою системою шляхом поетапної новелізації національного законодавства (вдосконалення чинного законодавства та прийняття нових нормативно-правових актів) з урахуванням acquis communautaire як сукупності спільних прав і взаємних зобов'язань країн-членів СС тощо.

Комплексний аналіз стану «євроадаптаційного» наукового дискурсу дає підстави для узагальненого дефініціювання адаптації національного законодавства до законодавства Європейського Союзу як грунтованого на міжнародній угоді планомірного процесу (комплексу односторонніх заходів) узгодження (зближення, наближення, пристосування, перетворення, приведення у відповідність до) нормативно-правових актів держави-реципієнта 3 європейськими стандартами (ідеалами) правового регулювання окремих видів суспільних відносин (правової регламентації пріоритетних сфер). Варто усвідомлювати, що про механічний юридико-формальний процес «правового запозичення» не йдеться, оскільки держава-реципієнт як повноправний член Ради Європи та низки інших європейських інституцій (програм) безпосередньо дотична до розробки і ствердження міжнародних та європейських принципів, норм і стандартів.

Адаптації законодавства притаманні такі характерні ознаки: є одним із засобів правової інтеграції та універсалізації права; здійснюється державою-кандидатом на вступ до Свропейського Союзу на підставі міжнародної угоди (у залежності від ступеню імперативності міжнародно-правових норм може здійснюватися державою довільно на власний розсуд або 3 дотриманням чітко визначених строків виконання зобов'язань щодо транспозиції актів надбання Спільноти); є правотворчим процесом; має динамічний односторонній характер; не $€$ всеосяжною, оскільки обмежується пріоритетними сферами, суттєвими для поглиблення економічної інтеграції та створення зони вільної торгівлі; спрямована на досягнення приблизної адекватності (еквівалентності, ідентичності) законів; не передбачає механічного запозичення норм законодавства СС; грунтується на засадах поваги до національного 
суверенітету, добровільності, лібералізму, планомірності, цілеспрямованості, безперервності, системності та чіткого усвідомлення іiї відповідності фундаментальним загальнонаціональним інтересам; має випереджаючий характер; передбачає консолідацію зусиль усіх гілок державної влади; є соціально акцептованою. Адаптація законодавства $є$ складовою політики добросусідства та партнерства, що передбачає створення на європейському континенті зони процвітання і сприятливого середовища. Поглиблена економічна інтеграція неможлива без впровадження в окремих секторах економіки базових положень регламентів, рішень, директив і рекомендацій Європейського Союзу. Процес адаптації складається з низки послідовних і безперервних етапів, що охоплюють перевірку (експертизу) проектів законодавчих актів на відповідність стандартам асquis $\mathrm{CC}$, уніфікацію юридичної термінології (створення глосарію), новелізацію чинного національного законодавства шляхом ухвали нових законів або внесення змін до чинних законів, розроблення і прийняття підзаконних нормативних актів на їх основі, здійснення моніторингу правозастосовної діяльності.

Сучасна доктрина адаптаційної діяльності у сфері права передбачає три можливі рівні зближення національного законодавства із законодавством Європейського Союзу. «Мінімальна адаптація» не пов'язана 3 перспективою набуття членства держави в Свропейському Союзі. Вона охоплює важливі для налагодження економічного співробітництва окремі пріоритетні сфери (у першу чергу комерційне право, права людини, реформу системи правосуддя). «Помірна адаптація» здійснюється у контексті реалізації системних економічних і соціально-політичних реформ, пов'язаних зі створенням зони вільної торгівлі 3 Європейським Союзом, що забезпечує дію чотирьох базових європейських свобод (руху осіб, капіталу, товарів і послуг). Тоді як «максимальна адаптація» має більш системний характер, оскільки зумовлена перспективою членства в Свропейському Союзі (після вступу держави до ЄС адаптація припиняється, надалі використовується ефективніший механізм гармонізації законодавства) $)^{9}$.

В Угоді про партнерство та співробітництво між Україною і Європейськими Співтовариствами та їх державами-членами формально закріплена обопільна зацікавленість сторін у встановленні приблизної адекватності законів лише у пріоритетних сферах, важливих для функціонування спільного ринку, економічного та валютного союзу. Натомість Угода про асоціацію закладає новий формат відносин між Україною та $Є C$, що передбачає перехід від принципів партнерства та співробітництва до якісного нового рівня політичної асоціації та економічної інтеграції. Угодою передбачено чіткі зобов'язання України щодо адаптації національної законодавства до законодавства ЄС на основі принципів демократії, верховенства права, поваги прав і свобод людини. У цьому документі адаптація розглядається як важливий правовий інструмент глибокої економічної інтеграції України до внутрішнього ринку СС шляхом створення поглибленої та всеохоплюючої зони вільної торгівлі. Зокрема, наголошено на нагальній необхідності «широкої регуляторної адаптації» законодавства України до асquis ЄС за визначеними в частині Угоди про економічне та секторальне співробітництво тридцятьма сферами правового регулювання, а також закріплено деталізовані переліки актів асquis $\mathrm{CC}$, що підлягають впровадженню в Україні у визначені строки. Відповідно до статті 114 Угоди закріплено два базові постульовані положення адаптації законодавства, а саме: Україна забезпечує, щоб існуючі закони та майбутнє законодавство поступово досягли сумісності з acquis $\mathrm{EC}$; адаптація розпочинається 3 дати підписання Угоди і поступово пошириться на всі елементи acquis $\mathrm{CC}$, зазначені у додатку XVII «Нормативно-правове наближення» до цієї Угоди. Відповідно до пункту 2 статті 2 додатку XVII встановлено: якщо законодавчий акт є регламентом або рішенням $\mathrm{EC}$, то він повинен стати, як такий, частиною національного законодавства України; якщо законодавчий акт $є$ директивою $С$, то за компетентними органами України залишається право вибору форми та способу його імплементації ${ }^{10}$. У Плані заходів з імплементації Угоди про асоціацію між Україною та ЄС на 2014-2017 роки, затвердженому розпорядженням Кабінету Міністрів України від 17.09.2014 № 847-р, міститься перелік понад 350 актів законодавства $\mathrm{CC}$, які мають бути транспоновані протягом двох-десяти років 3 моменту набуття чинності Угоди або окремих їі положень ${ }^{11}$.

Легітимізація національного інституційного механізму адаптації законодавства була здійснена шляхом ухвали Закону України «Про Загальнодержавну програму адаптації законодавства України до законодавства Свропейського Союзу». Відповідно до розділу 
VIII цього Закону повноваженнями у сфері адаптації законодавства наділено Верховну Раду України, Кабінет Міністрів України, уповноважений центральний орган виконавчої влади, Координаційну раду з адаптації законодавства України до законодавства Європейського Союзу. Така конфігурація інституційного механізму адаптації законодавства України до законодавства Європейського Союзу зберігалася останнього часу. Кожен суб'єкт адаптаційної діяльності функціонував у межах законодавчо визначеної компетенції.

Упродовж 2014-2016 років національний інституційний механізм адаптації законодавства було суттєво скориговано. Уряд вжив низку організаційно-правових заходів, сутність яких полягала у наступному:

- формальному закріпленні за Кабінетом Міністрів України повноважень щодо спрямування, координації та контролю у сфері європейської інтеграції з питання адаптації законодавства України до законодавства Європейського Союзу;

- віднесенні до компетенції віце-прем'єр-міністра 3 питань європейської та євроатлантичної інтеграції України питання «адаптації законодавства України до законодавства СС в Кабінеті Міністрів України, організації проведення моніторингу результатів роботи з такої адаптації», координації виконання Україною зобов'язань за Угодою про асоціацію Україна - СС та іншими міжнародними угодами і домовленостями між Україною та СС, а також представлення за рішенням Кабінету Міністрів України у Верховній Раді України позиції уряду щодо законопроектів, предмет правового регулювання яких спрямований на виконання зобов'язань України у рамках зазначеної Угоди або може істотно вплинути на виконання таких зобов'язань;

- інституціоналізації Урядового офісу з питань європейської інтеграції як окремого структурного підрозділу Секретаріату Кабінету Міністрів України, підпорядкованого Прем’єр-міністру України, віце-прем'єр-міністру з питань європейської та євроатлантичної інтеграції України, а також Міністру Кабінету Міністрів України. Урядовий офіс готує і подає Прем'єр-міністру України, віце-прем'єр-міністру з питань європейської та євроатлантичної інтеграції України пропозиції щодо підвищення ефективності здійснення заходів з адаптації законодавства України до права $\mathrm{CC}^{12}$. 3 лютого 2016 року цей орган уповноважено проводити в установленому порядку експертизу відповідності проектів нормативно-правових актів, які вносяться на розгляд Кабінету Міністрів України, міжнародно-правовим зобов'язанням України у сфері європейської інтеграції, а також врахування права Європейського Союзу (acquis $\mathrm{CC}$ ). Крім того, цей орган має забезпечувати здійснення перекладу асquis $\mathrm{CC}$ на українську мову, оновлення глосарія термінів асquis $\mathrm{CC}$.

Як наслідок, de facto була здійснена «ревізія» законодавчих положень щодо компетенції окремих суб'єктів у сфері адаптації законодавства. Кабінет Міністрів України, як вищий орган у системі органів виконавчої влади, сконцентрував увесь спектр відповідних повноважень, а Міністерство юстиції України було позбавлено статусу уповноваженого центрального органу виконавчої влади у сфері адаптації законодавства України до acquis communautaire.

Вважаємо, що проблема визначення правосуб'єктності Міністерства юстиції України у сфері адаптації законодавства потребує додаткового поглибленого дослідження. Особливу увагу слід звернути на одночасне збереження чинності двох положень про міністерство. У затвердженому 2011 року указом Президента України положенні закріплено широкі «євроадаптаційні» повноваження міністерства як спеціально уповноваженого центрального органу виконавчої влади у сфері адаптації законодавства України до законодавства Свропейського Союзу ${ }^{13}$. Водночас у відповідній постанові Кабінету Міністрів України повноваження Мінюсту зведено до здійснення науково-експертного, аналітичного, інформаційного та методологічного забезпечення виконання першого етапу реалізації Загальнодержавної програми адаптації законодавства України до законодавства Європейського Союзу ${ }^{14}$. Фактично йдеться про правову колізію, яка має вирішуватися з урахуванням юридичної сили нормативно-правових актів.

На нашу думку, перспектива вдосконалення інституційного механізму адаптації законодавства полягає у вжитті таких заходів:

- усуненні існуючих правових колізій (у першу чергу йдеться про визнання таким, що втратив чинність, Закону України «Про Загальнодержавну програму адаптації 
законодавства України до законодавства Європейського Союзу» або його новелізацію шляхом легітимізації сучасної євроадаптаційної моделі, а також про усунення наслідків існуючої конкуруючої компетенції Президента України та Кабінету Міністрів України при затвердженні Положення про Міністерство юстиції України);

- посиленні євроадаптаційної правосуб'єктності віце-прем'єр-міністра 3 питань європейської та євроатлантичної інтеграції України шляхом включення до складу Координаційної ради з адаптації законодавства України до законодавства Свропейського Союзу, делегування йому повноважень щодо забезпечення взаємодії уповноважених інституцій, здійснення зовнішньої комунікації з питань адаптації законодавства тощо;

- підвищенні інституційної спроможності Мін'юсту внаслідок повернення йому статусу спеціально уповноваженого центрального органу виконавчої влади у сфері адаптації законодавства України і делегування широких «євроадаптаційних» повноважень, що об'єктивно зумовлено усвідомленням виняткової важливості адаптації законодавства для реалізації євроінтеграційного курсу Української держави, необхідності системного вирішення завдань у сфері адаптації законодавства та наявності у Мін'юсту потужного інтелектуального ресурсу, відповідної «інституційної пам'яті» та позитивного досвіду реалізації системних заходів у цій сфері. Аналіз практики адаптаційної діяльності дає підстави стверджувати щодо доцільності делегування цих повноважень спеціалізованому структурному підрозділу Мін'юсту (можливо, відокремленому). Вважаємо, що Урядовий офіс з питань європейської інтеграції в умовах перевантаженості за обмеженої штатної чисельності неспроможний якісно забезпечити виконання широкого спектру завдань у сфері адаптації законодавства. Натомість у взаємодії з Мін'юстом цей інститут може забезпечувати підготовку інформаційно-аналітичних матеріалів щодо шляхів підвищення ефективності здійснення заходів з адаптації законодавства України до права $\mathrm{CC}$, виправдовуючи таким чином належність до складу Секретаріату Кабінету Міністрів України як постійно діючого органу, що забезпечує діяльність Кабінету Міністру України;

- активнішому використанні позитивного науково-експертного євроадаптаційного потенціалу спеціалізованих недержавних суб'єктів;

- оптимізації роботи Координаційної ради з адаптації законодавства України до законодавства Європейського Союзу шляхом чіткої артикуляції мети діяльності з урахуванням нормативно визначених завдань, інтенсифікації діяльності, підвищення якості підготовки засідань та обгрунтованості ухвалюваних рішень, забезпечення імперативності іiі рішень для органів місцевого самоврядування, покладання на структурний підрозділ Міністерства юстиції України обов'язку організаційно-технічного забезпечення ii діяльності, розширення персонального складу за рахунок включення представників профільних академічних і навчальних установ, інститутів громадянського суспільства, авторитетних зарубіжних експертів;

- запровадженні практики проведення репрезентативних науково-практичних конференцій (круглих столів, семінарів, тренінгів тощо) з метою публічного обговорення актуальних проблем адаптації законодавства, а також реалізації загальнонаціональних інформаційно-просвітницьких заходів.

Резюмуючи, зазначимо, що генеза соціально-правового феномена адаптації національного законодавства до законодавства Європейського Союзу об'єктивно зумовлена прагненням до легітимізації євроінтеграційного вектору державно-правового розвитку. Адаптація законодавства $є$ динамічним планомірним одностороннім процесом приведення (зближення, узгодження, пристосування) законів України та інших нормативноправових актів у відповідність 3 acquis communautaire 3 метою подолання економічного «ізоляціонізму», усунення правових колізій, досягнення несуперечності законодавства та одноманітності правового регулювання окремих видів суспільних відносин. На сучасному етапі державно-правового розвитку України адаптація законодавства не $\epsilon$ всеосяжною. Фактично вона $є$ початковою стадією досягнення стану сумісності (сполучності, еквівалентності) із законодавством СС в окремих сферах, визначальних для поглиблення торговельно-економічних зв'язків, поступової інтеграції країни-реципієнта до внутрішнього 
ринку ЄС. Водночас адаптація законодавства $€$ дієвим засобом співставлення універсально-цивілізаційного та специфічно-національного розуміння права, досягнення концептуально-нормативної спільності правового регулювання і ствердження європейського праворозуміння. Інституційний механізм адаптації вітчизняного законодавства до acquis communautaire потребує суттєвого коригування, у першу чергу шляхом відновлення інституційної спроможності Міністерства юстиції України як уповноваженого центрального органу виконавчої влади у сфері адаптації законодавства, посилення євроадаптаційної правосуб'єктності віце-прем'єр-міністра з питань європейської та євроатлантичної інтеграції України, покращання координації адаптаційної діяльності та іiї децентралізації за рахунок ширшого залучення до реалізації відповідних заходів недержавних інституцій та профільних експертів.

${ }^{1}$ Угода про партнерство і співробітництво між Україною та Свропейськими Співтовариствами та їх державами-членами від 14 червня 1994 року. - URL: http://zakon2.rada.gov.ua/laws/show/998_012 (дата звернення: 23.08.2016).

2 Національна індикативна програма на 2007-2010 роки. - URL: https://webcache. googleusercontent.com/search?q=cache:d6y8BN74HFoJ:https://eu.prostir.ua/ data\%3Ft3D1\%26q\%3D23 $5212+\& \mathrm{~cd}=8 \& \mathrm{hl}=\mathrm{ru} \& \mathrm{ct}=\mathrm{clnk} \& \mathrm{gl}=\mathrm{ua}$ (дата звернення: 23.08.2016).

${ }^{3}$ Національна індикативна програма на 2011-2013 роки. - URL: http://eeas.europa.eu/delegations/ ukraine/documents/eu_ua/2011_enpi_nip_ukraine_uk.pdf (дата звернення: 24.08.2016).

${ }^{4}$ Угода про асоціацію між Україною, з однієї сторони, та Європейським Союзом, Європейським співтовариством з атомної енергії і їхніми державами-членами, з іншої сторони. - URL: http://zakon5. rada.gov.ua/laws/show/984_011 (дата звернення: 24.08.2016).

5 Про затвердження Стратегії інтеграції України до Європейського Союзу: указ Президента України від 11 червня 1998 року № 615/98. - URL: http://zakon3.rada.gov.ua/laws/show/615/98 (дата звернення: 25.08.2016 ).

${ }^{6}$ Про Концепцію адаптації законодавства України до законодавства Європейського Союзу : постанова Кабінету Міністрів України від 16 серпня 1999 року № 1496. - URL: http://zakon2.rada.gov. ua/laws/show/1496-99-\%D0\%BF (дата звернення: 25.08.2016).

${ }^{7}$ Про Загальнодержавну програму адаптації законодавства України до законодавства Європейського Союзу : закон України від 18 березня 2004 року № 1624-IV. - URL: http://zakon5.rada.gov.ua/ laws/show/1629-15 (дата звернення: 23.08.2016).

8 Там само.

${ }^{9}$ Рабінович M. Гармонізація законодавства України та $\mathrm{CC}$ : теоретичний аспект. - URL: http:// pravotoday.in.ua/ru/press-centre/publications/pub-466/ (дата звернення: 24.08.2016).

${ }^{10}$ Угода про асоціацію між Україною, з однієї сторони, та Європейським Союзом, Свропейським співтовариством з атомної енергії і їхніми державами-членами, з іншої сторони. - URL: http://zakon5. rada.gov.ua/laws/show/984_011 (дата звернення: 23.08.2016).

${ }_{11}$ Про імплементацію Угоди про асоціацію між Україною, з однієї сторони, та Європейським Союзом, Свропейським Співтовариством з атомної енергії і їхніми державами-членами, з іншої сторони: розпорядження Кабінету Міністрів України від 17 вересня 2014 року № 847-p. - URL: http:// zakon2.rada.gov.ua/laws/show/847-2014-\%D1\%80 (дата звернення: 25.08.2016).

12 Про Урядовий офіс з питань європейської інтеграції: постанова Кабінету Міністрів України від 13 серпня 2014 року № 346. - URL: http://zakon2.rada.gov.ua/laws/show/346-2014-\%D0\%BF (дата звернення: 26.08.2016).

${ }^{13}$ Про затвердження Положення про Міністерство юстиції України : указ Президента України від 6 квітня 2011 року № 395. - URL: http://zakon5.rada.gov.ua/laws/show/395/2011 (дата звернення: 27.08.2016).

14 Про затвердження Положення про Міністерство юстиції України: постанова Кабінету Міністрів України від 2 липня 2014 року № 228. - URL: http://zakon0.rada.gov.ua/laws/show/228-2014$\%$ D0\%BF (дата звернення: 27.08.2016). 